\title{
Magdalena Perkowska
}

University of Bialystok, Poland

ORCID: 0000-0002-9495-132X

m.perkowska@uwb.edu.pl

\section{Popular Initiative as an Instrument of Migration Policy in Switzerland}

\author{
Inicjatywa ludowa jako instrument polityki migracyjnej w Szwajcarii
}

\section{SUMMARY}

The main aim of this article was to present the popular initiatives in Switzerland concerning migration. The initiatives were presented in chronological order and analysed from historical and current perspectives, starting from 1968 with the initiative "Anti-foreign empire" through 2018 with "For the moderated immigration (initiative of limitation)". The article focuses mainly on initiatives held in the $21^{\text {st }}$ century, as they were accepted by the people and led to changes of the Federal Constitution. The main research question is whether Swiss citizens may use popular initiative as an effective instrument influencing migration policy. The main hypothesis is that the popular initiative may be an effective instrument influencing migration policy. The author used the dogmatic method as the research method which refers to the analysis of the legislation and academic literature, based on library searches made in Switzerland. The article presents the main arguments of the initiator as well as the immigration situation, which was always a background for developing the idea. As the article focuses mostly on the initiative "Stop mass immigration" it presents in detail the arguments that encouraged people to vote in favour. Those arguments referred to e.g. real estate market, natural environment, labour market, social security, Swiss identity, culture and religion, criminality and asylum. The author also analysed the implementation of initiatives and attempts to answer the question whether the amendment of the Federal Constitution was effective.

Keywords: popular initiative; migration; foreigners

\section{INTRODUCTION}

Direct democracy is an integral element of Swiss political identity. It is supported by a huge majority of citizens and has led to remarkable political stability, has upheld both the legitimacy of the Swiss political system as a whole as well 
as the trust of citizens in the political process ${ }^{1}$. One of its instruments is a popular initiative that is a way to request an amendment to the Federal Constitution. The initiative may propose total or partial revision of the Federal Constitution. A popular initiative may be proposed by 100,000 persons eligible to vote within 18 months from the date of the official publication of the initiative. It touches many different issues of social and economic life. One of the problems that has been a subject of popular initiatives for dozens of times is the issue of immigration.

The following initiatives have been elaborated in the subject of immigrants and immigration ${ }^{2}$ :

1) 1968: Initiative "Anti-foreign penetration" - abandoned,

2) 1970: Initiative "Anti-foreign empire (Schwarzenbach)" - refused by $54 \%$,

3) 1974: Initiative "Anti-foreign empire and Switzerland overpopulation" refused by $65.8 \%$,

4) 1977: Initiative "To protect Switzerland" - refused by $70.5 \%$,

5) 1977: Initiative "To limit the number of naturalization" - refused by $66.2 \%$,

6) 1988: Initiative "Against over-foreignisation" - refused by $67.3 \%$,

7) 2000: Initiative "For a regulation of immigration" - refused by $63.8 \%$,

8) 2010: Initiative "For expulsion of foreign criminals" - accepted by $52.9 \%$,

9) 2014: Initiative "Stop mass immigration" accepted by 50.3\%,

10) 2014: Initiative "Stop overpopulation. Yes to the sustainable conservation of natural resources" - refused by $74.1 \%$,

11) 2017: Initiative "Let's get out of the impasse! Let's renounce the re-establishment of immigration quotas" - withdrawn,

12) 2018: Initiative "For the moderated immigration (initiative of limitation)" - the required number of signatures has been achieved, the Federal Council recommends the people reject the initiative.

So far among all twelve initiatives, nine have been subjected to the people's vote. Only two of them were accepted: "For expulsion of foreign criminals"3 and "Stop mass immigration". The initiatives concerning immigration pose a lot of controversies. The author would, therefore, like to analyse them and verify whether Swiss citizens may use popular initiatives as an effective instrument to influence

1 S. Geissbühler, Does direct democracy really work? A review of the empirical evidence from Switzerland, „Przegląd Politologiczny”2014, nr 4, DOI: https://doi.org/10.14746/pp.2014.19.4.6, p. 88.

2 E. Piguet, Economy versus the people? Swiss immigration policy between economic demand, xenophobia and international constraint, [in:] Dialogues on Migration Policy, eds. M. Giugni, F. Passy, Oxford 2006, p. 78; U. Windisch, Suisse-immigrés, quarante ans de débats 1960-2001, Lausanne 2002, pp. 125-141; M. Perkowska, The Migration Policy of Switzerland, „Przegląd Politologiczny" 2015, nr 3, DOI: https://doi.org/10.14746/pp.2015.20.3.3, p. 50.

3 M. Perkowska, Popular initiative as an instrument of criminal policy towards foreigners in Switzerland, „Białostockie Studia Prawnicze” 2019, nr 1, DOI: https://doi.org/10.15290/ bsp.2019.24.01.08, p. 105. 
migration policy. The main hypothesis is that popular initiatives may be effective instruments for influencing migration policy.

Before that main analysis begins, it is worth mentioning that the Swiss population doubled in size between 1936 and 2016, rising from 4.2 million to 8.4 million people. In 2016, the permanent resident population was comprised of 4.25 million women and 4.17 million $\mathrm{men}^{4}$. At the end of 2017, the share of foreign nationals in the permanent resident population amounted to $25.1 \%$. This share was rising systematically from the 1980 s. In 1980 it was $14.1 \%$, in $1990-16.4 \%$, in $2001-20 \%$, in $2010-22.4 \%$. To date 403,622 of the foreign residents were born in Switzerland and 1.7 million abroad, two thirds of the people born abroad come from an EU-28/EFTA Member States. The permanent foreign resident population registered an increase of roughly $3 \%$ in the previous year. The 10 most common nationalities in the permanent foreign resident population are Italian, German, Portuguese, French, Kosovar, Spanish, Serbian, Turkish, Macedonian and Austrian ${ }^{5}$. The cantons with the highest number of foreign populations are Zurich, Vaud, Geneva and Bern. However, the cantons with the highest proportion of foreign inhabitants are Geneva (40\%), Basel-Stadt (36\%) and Vaud (34\%). With 11\% and 12\%, the cantons of Appenzell Innerrhoden and Uri have the smallest proportion of foreign nationals, followed by the canton of Nidwalden with $14 \%$ and the cantons of Obwalden and Jura with $15 \%$ each $^{6}$.

\section{POPULAR INITIATIVES CONCERNING MIGRATION FROM A HISTORICAL PERSPECTIVE}

The first popular initiative aiming for the limitation of immigration to Switzerland was the "Anti-foreign penetration" launched in 1968 by the Zurich Democratic Party, a small party with nationalistic ideas 7 . This initiative appeared at the moment when the population of foreigners reached $15 \%$ of the Swiss population. The main idea of this initiative was to settle the maximum quota at $10 \%$ of foreigners among residents in Switzerland. The initiative was abandoned as the government accepted the Decree on the Reduction of Foreigners on 28 February 1968. This decree foresaw the reduction of foreign population by 3\% in 1968 and that next 3\% by the end of $1969^{8}$.

Continuous growth of the foreign population which reached $17 \%$ in 1970 led to tensions in the society, and to the introduction of a second popular initiative which

\footnotetext{
Federal Statistical Office, Switzerland's population 2016, Neuchâtel 2017, pp. 6-7.

Ibidem, p. 9.

Ibidem, pp. 7-8.

7 E. Piguet, H. Mahnig, Quotas d'immigration: L'expériance suisse, « Cahiers de migrations internationals $\gg 2000, n^{\circ} 30$, p. 9.

8 E. Piguet, L'immigration en Suisse : soixante ans d'entrouverture, Lausanne 2013, p. 27.
} 
the Swiss Action Committee called: "Anti-foreign empire". It is also known as the "Schwarzenbach initiative" because of its author's surname, a charismatic publisher and journalist connected to the Action Committee. The Schwarzenbach initiative was even stricter than the previous one from 1968 as it imposed the limit for the number of foreigners at the level of $10 \%$ for each canton (except for the Canton of Geneva, where the number of foreigners could reach $25 \%$ of the population). Nevertheless, the Schwarzenbach initiative was rejected in a public vote on 7 June 1970 by $54 \%$ of voters and the majority of cantons 9 .

Even though the Schwarzenbach initiative was unsuccessful it pushed the government to accept the "policy of global ceiling" which was the management of immigration flows based on centrally administered registries for foreigners and on the determination of annual global quotas ${ }^{10}$. This initiative also started a very intense period of the 1970s for numerous popular initiatives which aimed at further implementation of the policy against "over-foreignisation", however, those initiatives turned out to be ineffective and were rejected by the society ${ }^{11}$. The next "Anti-foreign empire and Switzerland overpopulation" launched by Initiative Committee of the National Action against the Foreign Empire which aimed at reducing the foreign population by up to 500,000 (foreign population reached in 1970: 1,059,000 and in $1973: 1,175,000$ ) was refused by a $65.8 \%$ vote on 20 October 1974 . This time the government won again using the argument of the catastrophic consequences of the initiative to the Swiss economy and diplomacy ${ }^{12}$.

The economic crisis was the first factor that caused a significant decrease in the number of foreigners employed. In total, the reduction of employment in all sectors amounted to $10 \%$. However, due to restrictive provisions on the legalization of foreigner stay, Swiss workers were saved from unemployment. Dismissed foreigners were not granted renewed stay permits, thus they were forced to leave Switzerland. Therefore, unlike other European countries, Switzerland "exported" the unemployed (those who lost their jobs as a result of the economic crisis), in this way saving the workplaces for the Swiss ${ }^{13}$. This, however, did not stop the "over-foreignisation" movements. The $4^{\text {th }}$ and $5^{\text {th }}$ initiatives against foreign empire "To protect Switzerland" and "To limit the number of naturalization" were voted on 13 March 1977. The $4^{\text {th }}$ initiative that aimed at the introduction of the maximum

${ }^{9}$ H. Mahnig, E. Piguet, La politique d 'immigration de 1948 a 1998: evolution et effets, [in:] Les migrations et la Suisse, éds. H.-R. Wicker, R. Fibbi, W. Haugh, Zurich 2003, p. 66.

${ }^{10}$ D.M. Gross, Immigration incentives and policy in Switzerland, [in:] International Migration, Economic Development \& Policy, eds. C. Ozden, M. Scghiff, London 2007, p. 187 ; H. Mahnig, La politique migratoire de 1970 au milieu des années 1980, [in:] Histoire de la politique de la migration, d'asile et d'integration en Suisse depuis 1948, éd. H. Mahnig, Zurich 2005, p. 136.

${ }^{11}$ E. Piguet, H. Mahnig, op. cit., p. 13 ; M. Perkowska, The Migration Policy ..., p. 44.

${ }^{12}$ E. Piguet, L'immigration en Suisse : soixante..., p. 35.

13 E. Piguet, H. Mahnig, op. cit., pp. 81-82; M. Perkowska, The Migration Policy..., p. 44. 
quota of $10 \%$ of foreigners among residents in Switzerland was refused by $70.5 \%{ }^{14}$. The $5^{\text {th }}$ aimed at establishing the yearly limit of 4,000 naturalization decisions and was also refused by $66.2 \%{ }^{15}$.

While analysing the initiative concerning the migration policy the initiative "Support a new policy towards foreigners" that aimed to save and guarantee the foreigners' rights is worth mentioning. This initiative launched by Working Community for a new policy on foreigners aimed at the continuation of the stabilization policy towards the number of foreign population. It guaranteed the same political rights for foreigners. A foreigner, once admitted into Switzerland should have a right to extend the residence permit and avoid forced departure as was the case in 1974-1976 due to the economic crisis. The authors also referred to the status of seasonal workers. This initiative was voted on 5 April 1981 and was refused by $84 \%{ }^{16}$.

The era of the 1970s was marked by unsuccessful initiatives aiming to limit the foreign population in Switzerland. The workers' need and economic growth was stronger than populist ideas. Although the initiatives failed, it did not stop the continuation of "over-foreignisation" initiatives. The next initiative did not concern establishing any limits of foreigners in the Swiss population.

The 1980s were a rather calm period almost without an initiative concerning the quotas of immigration, except one (i.e. "Against over-foreignisation") initiative which was the $6^{\text {th }}$ initiative against the over-foreignisation of Switzerland. The idea was to limit the number of residence permits issued to foreigners up to two thirds of the number of foreigners who left Switzerland the previous year, and to continue this process as long as the country's total population exceeds 6.2 million. The initiative also provided a limitation for the number of permits for cross-border and seasonal workers ${ }^{17}$. The initiative was voted on 4 December 1988 and was refused by $67.3 \%$ and the majority of all cantons ${ }^{18}$.

The initiative "For a regulation of immigration" was prepared by the Committee for a Limited Migration (Komitee für eine begrenzte Zuwanderung). The idea of the initiative was simple - the quota of foreign population in Switzerland could not exceed $18 \%$. This initiative was voted on 24 September 2000 and was refused by $63.8 \%$ and in the majority of all the cantons. This initiative was voted in the same

${ }^{14}$ Quatrième initiative populaire 'contre l'emprise étrangère', www.bk.admin.ch/ch/f/pore/vi/ vis112.html [access: 15.05.2019].

15 Votation No 266, Tableau récapitulatif, www.bk.admin.ch/ch/f/pore/va/19770313/det266.html [access: 15.05.2019].

${ }^{16}$ E. Piguet, L'immigration en Suisse : soixante..., pp. 39-40.

17 Initiative populaire fédérale 'pour la limitation de l'immigration', www.bk.admin.ch/ch/f/ pore/vi/vis168.html [access: 3.03.2020].

18 Votation No 355, Tableau récapitulatif, www.bk.admin.ch/ch/f/pore/va/19881204/det355.html [access: 15.05.2019]. 
year as the Bilateral Agreement with the European Union. Its failure was in favor of the government. Its success would be an important obstacle for the rapprochement of Switzerland to the EU, especially the free movement of persons ${ }^{19}$.

The $20^{\text {th }}$ century ended without any successful popular initiative concerning the migration policy towards foreigners although the Swiss migration policy had been evaluated a great deal in this period. The popular initiatives did not influence it directly but they revealed the continuous fear of over-foreignisation, which has been a constant of the Swiss immigration policy. Direct democracy makes it even more threatening to the extent that xenophobic parties can at any time attempt to block government action for a long time by imposing limits on the size of the foreign population in the Constitution. Such attempts occurred six times during the period of 1968-2000, not to mention numerous national or cantonal referendums aimed at blocking improvements in the status of migrants. On the other hand, the Swiss government has always succeeded, taking into account the best interests of the country and its economy and having in mind future immigration, to prevent xenophobic movements from achieving their goals ${ }^{20}$.

\section{THE $21^{\text {ST }}$ CENTURY}

The constellation of factors, which characterizes the Swiss immigration policy at the beginning of the $21^{\text {st }}$ century, is quite different from the previous century. From a clear opposition between interests of economy as a whole and the popular fear of "over-foreignisation", the situation has shifted toward a new alliance. The dominant fraction of economy, as well as the majority of the population that is hostile to massive immigration, have agreed to a new policy of free circulation in Europe, but to a strict selection of highly qualified immigrants from the rest of the world. This compromise should allow most of the economic needs to be met, while protecting against uncontrolled flows from non-European immigrants. Several sectors of the economy and the extreme wing of anti-immigration groups are left out in that compromise, but they lack strength to counteract ${ }^{21}$.

The thesis of E. Piguet who claims that the governments which are trying to formulate an immigration policy are caught between economic demands and the fear of popular xenophobia ${ }^{22}$ seems to be confirmed again by the Swiss case. It is

${ }^{19}$ E. Piguet, L'immigration en Suisse : soixante..., p. 64.

${ }^{20}$ Ibidem, p. 66.

${ }^{21}$ E. Piguet, L'immigration en Suisse : cinquante ans d'entrouverture, Lausanne 2004, pp. 70-71; M. Perkowska, The Migration Policy ..., p. 49.

${ }^{22}$ H. Mahnig, A. Wimmer, Country-Specific or Convergent? A Typology of Immigrant Policies in Western Europe, "Journal of International Migration and Integration" 2000, Vol. 1(2), DOI: https:// doi.org/10.1007/s12134-000-1001-9, pp. 198-199; M. Perkowska, The Migration Policy..., p. 50. 
on the international scene that antagonist forces can now be found, which could endanger the policy in the $21^{\text {st }}$ century. The evolution of the international law imposes to a growing extent policies which neither the national economy nor a majority of the population would have chosen. Anti-immigration groups have been quick to realize that new threat: more than immigration policies per se, it is nowadays the Swiss participation in the international system that became their new target ${ }^{23}$.

The Swiss nation took a very important decision on 9 February 2014 which was the adoption of the popular initiative "Stop mass immigration" 24 aimed at stopping mass immigration. It thereby expressed its support for a change of system in Switzerland's immigration policy. The new constitutional provisions stated that immigration should be restricted by means of quantitative limits and quotas ${ }^{25}$. The Federal Council was supposed to set to work on implementing these without delay. Until the relevant implementing legislation comes into force, the free movement of persons between the EU and EFTA Member States and Switzerland applies as before ${ }^{26}$.

The initiators of the initiative indicated many negative aspects which are consequences of immigration to Switzerland. According to the "Argumentaire", the disadvantages concern: roads and railways, energy consumption, real estate market, natural environment, labour market, social security, Swiss identity, culture and religion, criminality and asylum. Out of the multitude of negative consequences mentioned above, the author will focus on the three most important (according to the initiators) and most fragile aspects such as labour market, social security and criminality. As far as the labour market is concerned, the higher unemployment rates were indicated

${ }^{23}$ E. Piguet, Economy versus the people..., p. 87.

24 The initiative was launched by Swiss People's Party (Schweizerische Volkspartei; Union Démocratique du Centre; Unione Democratica di Centro) which has following policy concerning immigration, foreigners and security: "Switzerland has always welcomed foreign workers generously, but in a controlled manner, offering them opportunities for professional development. During several votes, the Swiss people made it clear that they wanted a controlled immigration with clear rules valid for all. People who want to live in Switzerland must respect the legal system of this country, integrate and ensure their own subsistence. Only immigrants who meet these conditions must have the opportunity to naturalize after a certain period of time. [...] Switzerland was once one of the safest countries in the world. A negligent policy, lax enforcement of existing laws and the opening of borders with membership of the Schengen area have resulted in Switzerland becoming one of the countries in Europe with a high crime rate. In order to prevent Switzerland from becoming a criminal Eldorado, the sentences must be toughened and the enforcement of the criminal law must be more rigorous" (Politique concernant les étrangers, www.udc.ch/parti/positions/themes/politique-des-etrangers [access: 10.02.2020]; Sécurité, droit et ordre, www.udc.ch/parti/positions/themes/politique-de-la-securite [access: 17.01.2020]).

${ }^{25}$ E. Piguet, H. Mahnig, op. cit., pp. 41-42 ; S. Hurst, Comment définir les chiffres maximaux admissibles, [in:] Immigration sous contrôle, éd. C.H. Cluve, Avenir Suisse - Avenir spécial 2014, pp. 7-9.

26 Implementing the new constitutional provisions on immigration: questions and answers, www. eda.admin.ch/dam/mission-eu-brussels/en/documents/FAQ_Umsetzung_MEI_JAI_EN.pdf [access: 3.03.2020]. 
among foreigners, much higher among foreigners than Swiss nationals. Another problem is that it is enough to work in Switzerland for only 4 weeks (employment accompanied with unemployment insurance) to receive the same unemployment benefit as a Swiss national after being hired for 12 months $^{27}$. It was also indicated that young immigrants from the EU push out other long-term residents from the Swiss labour market as the younger ones cost less for employers. Immigration causes the "dumping" of Swiss professionals, as younger immigrants are less expensive, particularly in border regions. The cross-border workers work not only in the border regions but also inside the country using the country's infrastructure and resources ${ }^{28}$. As regards the issue of social security, the Swiss Peoples' Party indicates an already weak financial condition of social institutions which is also abused by the migrants that aim only in unlawful claim for social insurance or social assistance benefits ${ }^{29}$. Switzerland, like other EU countries, is facing the problem of the "immigration of poverty". In the area of criminality, the initiators indicated that the criminality of foreigners increases every year, especially in the area of violent crimes, and in 2012 $58 \%$ of the convicts were foreign nationals. Moreover, the authors stress that the proportion of foreigners in prisons is three times higher than the share of foreigners in the global population. It is also indicated that those numbers could be higher as some of the foreigners were naturalised. The criminality of foreigners is supplementary to the argument for the independent management of immigration and taking decision on who can immigrate into the Swiss territory. The argumentation refers also to the problem of false asylum-seekers (people who, in fact, are not persecuted in their country) who abuse the asylum procedure and then use the social benefits as a source of income and also commit crimes ${ }^{30}$.

Those facts were true ${ }^{31}$, however a simple presentation of statistical data is not enough without criminological analysis, and can be misleading. It was also strongly

${ }^{27}$ Comité interpartis contre l'immigration de masse, Argumentaire Initiative populaire « contre l'immigration de masse ", 2013, www.parlament.ch/centers/documents/fr/argumentarien-pro-f.pdf [access: 10.02.2020], p. 16 .

${ }^{28}$ Ibidem, p. 19.

${ }^{29}$ Ibidem, p. 26.

30 Ibidem, pp. 32-34.

${ }^{31}$ In the years 2009-2015, offences against life and limb and violent crimes constitute the second largest group of offences committed both by Swiss nationals and foreigners. Extreme violent criminal offences such as murder, grievous bodily harm, rape and robbery constitute less than $5 \%$ of all violent crimes recorded by the Swiss law enforcement authorities. Other violent offences include domestic violence such as offences against physical integrity and sexual offences with most being connected with violent behaviour between couples. See Statistique policière de la criminalité (SPC), Rapport annuel 2015, Neuchâtel 2016, p. 8; S. Steiner, Häusliche Gewalt, Migrationshintergrund und Strafverfolgung, [in:] Migration, Kriminalität und Strafrecht: Fakten und Fiktion, Migration, criminalité et droit pénal: mythes et réalité, hrsg. v. D. Fink, A. Kuhn, C. Schwarzenegger, Berne 2013, p. 171; M. Perkowska, Criminality by Foreign Nationals in Switzerland - Criminological Approach, Białystok 2019, p. 91. 
stressed that foreigners commit mostly violent crimes such as homicide, assault, robbery, rape, trafficking in human beings, false imprisonment and abduction ${ }^{32}$. That information was simply given on the basis of statistical data from the Federal Statistical Office without any criminological analysis ${ }^{33}$. If we look at the period of 2009-2015 foreigners who were granted refugee status or some other form of protection by the Swiss authorities committed the least number of offences (compared with groups of foreign residents and others $\left.{ }^{34}\right)^{35}$.

A few months after voting on the popular initiative "Stop mass immigration", on 30 of November 2014, the new initiative "Stop overpopulation. Yes to the sustainable conservation of natural resources" was refused by $74.1 \%$. The initiative aimed to conserve natural resources, to this end, any increase in Switzerland's permanent resident population growth attributable to migration should be limited to $0.2 \%$ (of the permanent resident population) per year and voluntary family planning should be encouraged as part of international development cooperation programmes ${ }^{36}$.

On 11 February 2015, the Federal Council took various decisions on the implementation of the new constitutional provisions accepted on 9 February 2014. It approved the draft of the new legislation on foreign nationals and additional measures to make better use of the potential workforce within Switzerland. It also made a final decision on the negotiating mandate with the EU on the Agreement on the Free Movement of Persons ${ }^{37}$.

The new article (i.e. Article $121 \mathrm{a}^{38}$ ) of the Federal Constitution contains two assignments: introducing a new immigration system and negotiating with the EU

32 Union démocratique du centre, Oui à l'initiative populaire pour le renvoi des étrangers criminels (initiative sur le renvoi), Argumentaire pour la votation du 28 novembre 2010, www.initiative-pour-le-renvoi.ch/fr/downloads/arg_ausschaffungsinitiative_lang_frz.pdf [access: 10.02.2020], pp. 6-7. See also M. Tomczyk, The decision-making process in Swiss foreign policy at the beginning of the $21^{s t}$ century, „Przegląd Politologiczny” 2014, nr 3, DOI: https://doi.org/10.14746/pp.2014.19.3.4, p. 51.

${ }_{33}$ M. Perkowska M., Popular initiative..., p. 111.

34 "Others" is the broadest group which includes: cross-border commuters (permit G), short term residents (permit L), tourists, asylum-seekers whose applications have been rejected, foreigners who are subject to deportation, foreigners staying illegally, foreigners in procedure for short-term work in Switzerland, foreigners whose status is not defined. See Statistique policière de la criminalité (SPC), op. cit., p. 26.

${ }^{35}$ M. Perkowska, Criminality..., p. 97.

${ }^{36}$ See Initiative populaire fédérale 'Halte à la surpopulation - Oui à la préservation durable des ressources naturelles', www.bk.admin.ch/ch/f/pore/vi/vis406.html [access: 3.03.2020].

${ }^{37}$ M. Perkowska, The Migration Policy..., pp. 50-51.

38 The Article 121a of Federal Constitutions states as follows: 1. Switzerland shall control the immigration of foreign nationals autonomously. 2. The number of residence permits for foreign nationals in Switzerland shall be restricted by annual quantitative limits and quotas. The quantitative limits apply to all permits issued under legislation on foreign nationals, including those related to asylum matters. The right to permanent residence, family reunification and social benefits may be restricted. 3. The annual quantitative limits and quotas for foreign nationals in gainful employment 
on an amendment to the Agreement on the Free Movement of Persons (AFMP). These two assignments must have been completed by February 2017 according to Article $197 \S 11$ of the Federal Constitution that states international agreements that contradict Article 121 a must be renegotiated and amended within 3 years of its adoption by the People and the Cantons. In case the implementing legislation for Article 121 a has not come into force within 3 years of its adoption by the People and the Cantons, the Federal Council will need to issue temporary implementing provisions in the form of an ordinance.

The immigration system that the Federal Council has devised contains annual quantitative limits and quotas for all foreign nationals and provides that Swiss residents should be given priority when recruiting new staff. The admission of EU citizens will be regulated by the AFMP as before, but the agreement will have to be amended in line with the constitutional requirements. The results of the negotiations being sought with the EU are, therefore, key to the draft legislation. For citizens of third countries, the draft legislation being submitted for consultation provides quotas and the prioritization of existing Swiss residents, as was previously the case.

The Federal Council also approved the mandate to negotiate with the EU on amendments to the AFMP. The mandate assigns the task of adapting the agreement so that Switzerland will be able to control immigration levels autonomously and limit immigration while safeguarding general economic interests. At the same time, Switzerland will maintain the bilateral path as the basis for its relations with the EU. Under the mandate, both objectives must be pursued equally ${ }^{39}$.

The position of the EU was clear from the very beginning:

The principle of non-discrimination, including equal treatment of all EU Member States, the right to exercise an economic activity and reside on the territory of the other party and the standstill clause constitute the essential basis of the consent of the EU to be bound by the agreement. Renegotiating these principles with the objective of introducing quantitative limits and quotas, combined with a preference for Swiss nationals would be in fundamental contradiction to the objective of the Agreement on the Free Movement of Persons ${ }^{40}$.

must be determined according to Switzerland's general economic interests, while giving priority to Swiss citizens; the limits and quotas must include cross-border commuters. The decisive criteria for granting residence permits are primarily an application from an employer, ability to integrate, and adequate, independent means of subsistence. 4. No international agreements may be concluded that breach this Article. 5. The law shall regulate the details.

39 M. Perkowska, The Migration Policy..., p. 51.

${ }^{40}$ Catherine Aston, High Representative, Vice President of the European Commission, Letter from 24 of July 2014 to the H.E. Didier Berkhalter, President of the Swiss Confederation, www.dfae. admin.ch/dam/dea/de/documents/eu/Antwort-EU-auf-Schweizer-Revisionsbegehren-24-7-2014 EN.pdf [access: 28.05.2019]. 
As a result (as of July 2019), the Federal Council introduced changes to be implemented in Article 121a of the Federal Constitution, however, only in the form of changes in the decrees (entered into force on 1 July 2018). In particular, the adopted law provides for the obligation to communicate vacancies in occupational categories with an unemployment rate at or above a certain threshold. In view of the results of the consultation on the amendments to ordinances, the Federal Council decided to proceed in stages: the threshold value applicable from 1 July 2018 will be $8 \%$, before decreasing to $5 \%$ on 1 January 2020 . Another amendment introduced concerns, in particular, making better use of the potential of the workforce in Switzerland. Concretely, an obligation to communicate vacant positions will give a head start to people registered with the public employment service in Switzerland. Those implementing laws are compatible with the AFMP and, therefore, also preserve other bilateral agreements with the EU.

Looking into the past between 2008 and 2014, Switzerland was entitled to reintroduce quotas (according to the AFMP) without retaliation from the EU. Under a special safeguard clause (ventilation clause) if the immigration rate was, for a given year, more than $10 \%$ higher than the average of the previous 3 years, in the case Switzerland could, for the next 2 years, limit immigration to the average of the previous 3 years increased by $5 \%$. The Federal Council made use of this possibility on 24 April 2013. Between 1 June 2013 and 31 May 2014, EU-1 $7^{41}$ nationals were thus subject to specific quotas of residence permits (EU B license/EFTA). Since 1 June 2014, EU-17 nationals again benefit from the free movement of persons ${ }^{42}$. This is the current regime.

Despite the fact that the people accepted the initiative of "Stop mass immigration", its implementation posed many difficulties on the international level ${ }^{43}$, which resulted in launching a new initiative "Let's get out of the impasse! Let's renounce the re-establishment of immigration quotas". The idea of this initiative was simple, just to withdraw Article 121a of the Federal Constitution introduced on the basis of the initiative "Stop mass immigration". The aim of the applicants was to maintain bilateral agreements with the EU that are threatened by the existence of Article 121a of the Federal Constitution ${ }^{44}$. This initiative was, however, withdrawn by the applicants, as it was not recommended by the Federal Council.

${ }^{41}$ EU-17 are the following countries: Austria, Belgium, Cyprus, Denmark, Finland, France, Germany, Greece, Ireland, Italy, Luxembourg, Malta, the Netherlands, Portugal, Sweden, Spain, the United Kingdom.

${ }^{42}$ Département fédéral de justice et police, Secrétariat d'Etat au migrations, Directives et commentaires concernant l'introduction progressive de la libre circulation des personnes, Bern-Wabern 2019, p. 10.

${ }_{43}$ See M. Rachwał, Citizens' initiatives in Switzerland, „Przegląd Politologiczny” 2014, nr 3, DOI: https://doi.org/10.14746/pp.2014.19.3.3, p. 40.

${ }^{44}$ Message relatif à l'initiative populaire « Sortons de l'impasse! Renonçons à rétablir des contingents d'immigration », Conseil fédéral 2017, p. 3169. 
As the Swiss People's Party was not satisfied by the state of implementation Article 121a of the Federal Constitution, especially since there were no changes introduced into the AFMP, a new initiative was launched. On 16 January 2018 the common committee of the initiative composed of Action for the Independent and Neutral Switzerland and the Swiss People's Party started the collection of signatures for the initiative "For the moderated immigration (initiative of limitation)". On 25 September 2018 the Federal Council found the initiative valid. The new initiative proposed the introduction of Article $121 \mathrm{~b}$ into the Federal Constitution that guaranteed the autonomy of Switzerland in regulating the immigration of foreign nationals. There would be no possibility to conclude new international treaties or other obligations of international law that would grant a regime free movement of persons to foreign nationals. Moreover, the binding international treaties and other existing international law obligations could not be modified or extended contrary to those provisions. The transitory regulations proposed to be introduced into Article $197 \S 12$ of the Federal Constitution state that within 12 months from the acceptance by the people and cantons of the initiative, the AFMP will be ceased on the basis of negotiation between Switzerland and the EU.

This is the strongest and least compromising idea for the Federal Council that, according to the applicants', will finally end the free movement of persons between Switzerland and the EU. The initiative does not exclude immigration to Switzerland, nor the bilateral agreements with the EU. This will be possible on the basis of a unilateral agreement stating the quotas for the frontaliers or the annual quotas for residence and work permits for other foreigners. There will be no possibility to conclude any international agreement that will grant the unlimited free movement of persons in any form. If it refers to the Agreement on Free Movement of Persons it should be frozen, suspended and possibly modified so that EU citizens no longer have a quasi-automatic right to work in Switzerland, to benefit from Swiss social insurance or to establish themselves freely. If these negotiations with the EU do not succeed, the Federal Council must terminate the AFMP within a month ${ }^{45}$.

Referring to the initiative of June 2019 "For the moderated immigration (initiative of limitation)" the Federal Council decided to recommend that the people reject the initiative (without elaborating any counter-proposal ${ }^{46}$. The main argument given by the Federal Council is that the introduction of Article 121b to the Federal Constitution would, in consequence, cause the termination of the AFMP. This would have significant damaging consequences for Switzerland. The AFMP is, on

45 Action pour une Suisse indépendante et neutre (ASIN) et de l'Union démocratique du centre, Argumentaire du comité d'initiative "Pour une immigration modérée (initiative de limitation) ", Berne 2018, pp. 6-7.

${ }^{46}$ Message relatif à l'initiative populaire « Pour une immigration modérée (initiative de limitation) », Conseil fédéral 2019, p. 1. 
the whole a series of Bilateral Agreements I, the one that ensures the greatest economic advantage. It contributes to the creation and maintenance of jobs in Switzerland and also gives Swiss citizens the right to live and work in the EU. The end of the AFMP will cause the guillotine clause for all Bilateral Agreements ${ }^{47}$. The date of vote is still unknown, however it is already called the vote for Bilaterals I.

\section{CONCLUSIONS}

The Swiss political system gives immigration policy a very strong importance in the public debate and constantly puts the government under pressure. It is, however, not obvious that it has had a major concrete impact on the levels of immigration over the past 50 years. The vox populi, vox dei system does not make Switzerland such a different case from the other liberal democratic immigration countries. Economic demand remains an ever strengthening factor, as well as international context ${ }^{48}$. If we try to answer the research question whether Swiss citizens may use the popular initiative as an effective instrument to influence migration policy, the response is not obvious. The example of the initiative "Stop mass immigration" shows that the people's vote may lead to important change in the Federal Constitution, which is also important from the international position of the country. However, the question arises whether those changes were effective and led the initiators to their aim. In this case, the answer must be negative. The results of the next vote on the initiative of limitation will be the final step, but in the author's opinion it is less likely that the Swiss nation will decide to introduce Article 121b to the Federal Constitution and in consequence renounce the Bilaterals.

The analysis made in this article confirms that the fear of over-foreignisation is a constant feature of the Swiss migration policy. It is more dangerous when the populist parties reach for the instrument of popular initiative that leads to changes in the Federal Constitution. This shows how one initiative (2014) and its "sister" initiatives $(2017,2018)$ can block the government actions for months, as the governments try to find the best solution that respects the result of the vote while respecting international commitments. The last one is mostly influenced by an economic demand. This is the constant issue of the Swiss government to find balance between the economic interest and vox populi.

${ }^{47}$ Ibidem, p. 23, 48.

${ }^{48}$ E. Piguet, Economy versus the people..., p. 86. 


\section{REFERENCES}

Action pour une Suisse indépendante et neutre (ASIN) et de l'Union démocratique du centre, $A r$ gumentaire du comité d'initiative " Pour une immigration modérée (initiative de limitation) », Berne 2018.

Catherine Aston, High Representative, Vice President of the European Commission, Letter from the 24 of July 2014 to the H.E. Didier Berkhalter, President of the Swiss Confederation, www.dfae. admin.ch/dam/dea/de/documents/eu/Antwort-EU-auf-Schweizer-Revisionsbegehren-24-7-2014 EN.pdf [access: 28.05.2019].

Comité interpartis contre l'immigration de masse, Argumentaire Initiative populaire " contre l'immigration de masse », 2013, www.parlament.ch/centers/documents/fr/argumentarien-pro-f.pdf [access: 10.02.2020].

Département fédéral de justice et police, Secrétariat d'Etat au migrations, Directives et commentaires concernant l'introduction progressive de la libre circulation des personnes, Bern-Wabern 2019.

Federal Statistical Office, Switzerland's population 2016, Neuchâtel 2017.

Geissbühler S., Does direct democracy really work? A review of the empirical evidence from Switzerland, „Przegląd Politologiczny” 2014, nr 4, DOI: https://doi.org/10.14746/pp.2014.19.4.6.

Gross D.M., Immigration incentives and policy in Switzerland, [in:] International Migration, Economic Development \& Policy, eds. C. Ozden, M. Scghiff, London 2007.

Hurst S., Comment définir les chiffres maximaux admissibles, [in:] Immigration sous contrôle, éd. C.H. Cluve, Avenir Suisse - Avenir spécial 2014.

Implementing the new constitutional provisions on immigration: questions and answers, www.eda. admin.ch/dam/mission-eu-brussels/en/documents/FAQ_Umsetzung_MEI_JAI_EN.pdf[access: 3.03.2020].

Initiative populaire fédérale 'Halte à la surpopulation-Oui à la préservation durable des ressources naturelles', www.bk.admin.ch/ch/f/pore/vi/vis406.html [access: 3.03.2020].

Initiative populaire fédérale 'pour la limitation de l'immigration', www.bk.admin.ch/ch/f/pore/vi/ vis168.html [access: 3.03.2020].

Mahnig H., La politique migratoire de 1970 au milieu des années 1980, [in:] Histoire de la politique de la migration, d'asile et d'integration en Suisse depuis 1948, éd. H. Mahnig, Zurich 2005.

Mahnig H., Piguet E., La politique d 'immigration de 1948 a 1998: evolution et effets, [in:] Les migrations et la Suisse, éds. H.-R. Wicker, R. Fibbi, W. Haugh, Zurich 2003.

Mahnig H., Wimmer A., Country-Specific or Convergent? A Typology of Immigrant Policies in Western Europe, "Journal of International Migration and Integration" 2000, Vol. 1(2),

DOI: https://doi.org/10.1007/s12134-000-1001-9.

Message relatif à l'initiative populaire « Pour une immigration modérée (initiative de limitation) », Conseil fédéral 2019.

Message relatif à l'initiative populaire « Sortons de l'impasse! Renonçons à rétablir des contingents d'immigration », Conseil fédéral 2017.

Perkowska M., Criminality by Foreign Nationals in Switzerland - Criminological Approach, Białystok 2019.

Perkowska M., Popular initiative as an instrument of criminal policy towards foreigners in Switzerland, „Białostockie Studia Prawnicze” 2019, nr 1,

DOI: https://doi.org/10.15290/bsp.2019.24.01.08.

Perkowska M., The Migration Policy of Switzerland, „Przegląd Politologiczny” 2015, nr 3, DOI: https://doi.org/10.14746/pp.2015.20.3.3.

Piguet E., Economy versus the people? Swiss immigration policy between economic demand, xenophobia and international constraint, [in:] Dialogues on Migration Policy, eds. M. Giugni, F. Passy, Oxford 2006. 
Piguet E., L'immigration en Suisse : cinquante ans d'entrouverture, Lausanne 2004.

Piguet E., L'immigration en Suisse : soixante ans d'entrouverture, Lausanne 2013.

Piguet E., Mahnig H., Quotas d'immigration: L'expériance suisse, « Cahiers de migrations internationals $\gg 2000, \mathrm{n}^{\circ} 30$.

Politique concernant les étrangers, www.udc.ch/parti/positions/themes/politique-des-etrangers [access: 10.02.2020].

Quatrième initiative populaire 'contre l'emprise étrangère', www.bk.admin.ch/ch/f/pore/vi/vis112. html [access: 15.05.2019].

Rachwał M., Citizens' initiatives in Switzerland, „Przegląd Politologiczny” 2014, nr 3, DOI: https://doi.org/10.14746/pp.2014.19.3.3.

Sécurité, droit et ordre, www.udc.ch/parti/positions/themes/politique-de-la-securite [access: 17.01.2020].

Statistique policière de la criminalité (SPC), Rapport annuel 2015, Neuchâtel 2016.

Steiner S., Häusliche Gewalt, Migrationshintergrund und Strafverfolgung, [in:] Migration, Kriminalität und Strafrecht: Fakten und Fiktion, Migration, criminalité et droit pénal: mythes et réalité, hrsg. v. D. Fink, A. Kuhn, C. Schwarzenegger, Berne 2013.

Tomczyk M., The decision-making process in Swiss foreign policy at the beginning of the $21^{\text {st }}$ century, „Przegląd Politologiczny” 2014, nr 3, DOI: https://doi.org/10.14746/pp.2014.19.3.4.

Union démocratique du centre, Oui à l'initiative populaire pour le renvoi des étrangers criminels (initiative sur le renvoi), Argumentaire pour la votation du 28 novembre 2010, www. initiative-pour-le-renvoi.ch/fr/downloads/arg_ausschaffungsinitiative_lang_frz.pdf [access: 10.02.2020].

Votation No 266, Tableau récapitulatif, www.bk.admin.ch/ch/f/pore/va/19770313/det266.html [access: 15.05 .2019$]$.

Votation No 355, Tableau récapitulatif, www.bk.admin.ch/ch/f/pore/va/19881204/det355.html [access: 15.05.2019].

Windisch U., Suisse-immigrés, quarante ans de débats 1960-2001, Lausanne 2002.

\section{STRESZCZENIE}

Głównym celem artykułu było przedstawienie inicjatyw ludowych w Szwajcarii dotyczących migracji. Inicjatywy zostały przedstawione w porządku chronologicznym i poddane analizie z perspektywy historycznej: począwszy od 1968 r. i inicjatywy „Przeciwko zagranicznemu imperium”, do inicjatywy z 2018 r. - „Dla umiarkowanej imigracji (inicjatywa ograniczająca)”. Skoncentrowano się głównie na inicjatywach, które miały miejsce w XXI w., ponieważ zostały zaakceptowane przez naród i doprowadziły do zmian w Konstytucji Federalnej. Główne pytanie badawcze brzmi następująco: Czy obywatele Szwajcarii mogą wykorzystać inicjatywę ludową jako skuteczny instrument wpływający na politykę migracyjną? Z kolei główna hipoteza zakłada, że inicjatywa popularna może być skutecznym instrumentem wpływającym na politykę migracyjną. Autorka zastosowała metodę dogmatyczną jako metodę badawczą. Dokonano analizy ustawodawstwa i literatury naukowej w oparciu o kwerendy biblioteczne przeprowadzone w Szwajcarii. W artykule opisano główne argumenty wnioskodawców oraz sytuację imigracyjną, która zawsze była podstawą do wystąpienia z inicjatywą. Najwięcej uwagi poświecono inicjatywie „Stop masowej imigracji”, przedstawiając szczegółowo argumenty wnioskodawców, które miały zachęcić społeczeństwo do jej poparcia. Były to argumenty dotyczące wpływu imigracji m.in. na rynek nieruchomości, środowisko naturalne, rynek pracy, zabezpieczenie społeczne, szwajcarską tożsamość, kulturę i religię oraz przestępczość i azyl. Analizie poddano również realizację inicjatywy i podjęto próbę udzielenia odpowiedzi na pytanie, czy zmiana Konstytucji Federalnej była skuteczna.

Slowa kluczowe: inicjatywa ludowa; migracja; cudzoziemcy 